Eur. J. Clin. Chem. Clin. Biochem.

Vol. 29, 1991, pp. $731-735$

(C) 1991 Walter de Gruyter \& Co.

Berlin - New York

Digoxygenin-Labelled DNA-Probe:

\title{
A Rapid Non-Radioactive Method for Hepatitis B Virus DNA Detection in Serum
}

By Maria Buti ${ }^{1}$, R. Jardi ${ }^{1}, F$. Rodriguez-Frias ${ }^{1}, J$. A. Arranz ${ }^{1}, J$. M. Casacuberta ${ }^{2}$, Blanca Sansegundo ${ }^{2}, P$. Puigdomenech $^{2}, R$. Esteban ${ }^{1}$ and J. Guardia ${ }^{1}$

1 Liver Unit, Departments of Internal Medicine and Biochemistry, Hospital Valle Hebrón, Universidad Autónoma, Barcelona, Spain

${ }^{2}$ Centre d'Investigacio i Desenvolupament, C.S.I.C., Barcelona, Spain

(Received April 2/July 17, 1991)

Summary: The sensitivity and specificity of two non-radioactive spot hybridization assays for hepatitis B virus DNA (HBV-DNA) using biotin and digoxygenin-labelled DNA probes were investigated in parallel in 122 serum samples from patients with chronic hepatitis B and 50 controls. The results were compared with an isotopic technique using a ${ }^{32} \mathrm{P}$-labelled probe.

HBV-DNA was detected in $56(80 \%)$ out of 70 hepatitis B "e" antigen ( $\mathrm{HBeAg}$ )-positive cases and in $4(8 \%)$ out of 52 antibody to hepatitis B "e" antigen (anti-HBe)-positive cases using the digoxygenin or ${ }^{32} \mathrm{P}-$-labelled probes. No false positives were found with either method. Using the biotin-labelled probe, $16 \%$ of sera gave discordant results, which were considered to be false positive. The time required for detection of serum HBVDNA was 2 hours for the non-radioactive probes and 16 hours for the isotopic probes.

This study suggests that the digoxygenin-labelled probe for detection of HBV-DNA is the most rapid and sensitive method for routine diagnosis of viral replication in clinical laboratories.

\section{Introduction}

Detection of hepatitis B virus (HBV) DNA in serum provides an important diagnostic tool for studying viral replication in chronic hepatitis $B(1,2)$. Nucleic acid hybridization techniques using ${ }^{32} \mathrm{P}$-labelled probes are commonly used for routine analysis because they are rapid, require small-amounts of serum and allow simultaneous treatment of about one hundred samples $(3,4)$. Their disadvantage lies in the use of radioisotopes, which have short half-lives, are expensive and cannot be handled easily in a routine diagnostic laboratory. A variety of methods have been proposed to replace the radioactive labelling of probes, such as the chemical modification of detectable DNA with monoclonal antibodies, fluorescein and photobiotin (5-7), and the incorporation of bio- tin or digoxygenin-labelled nucleotides by enzymatic reaction $(8-10)$. Some of these techniques have proved to be slightly less sensitive than the radioactive methods in HBV-DNA detection $(11,12)$.

Our interest resides in finding accurate and rapid nonradioactive methods suitable for routine diagnosis in clinical laboratories, for HBV-DNA detection in human serum samples. In this work we investigate and compare the sensitivity, the specificity and the time necessary for detection of HBV-DNA, using DNA probes prepared by: incorporation of biotin (biotin11-dUTP) into DNA by standard nick-translation procedures; incorporation of digoxygenin (digoxygenin-dUTP) into DNA by random priming; and a standard radioactive ${ }^{32} \mathrm{P}$ nick-translation procedure. 


\section{Patients and Methods}

Two groups of patients were studied:

Group I comprised 122 patients with chronic hepatitis type B, as documented by the presence of hepatitis $B$ surface antigen ( $\mathrm{HBsAg}$ ) and elevated alanine aminotransferase levels in serum for at least 6 months. Most of them had histological evidence of chronic hepatitis or cirrhosis. Seventy $(57 \%)$ were $\mathrm{HBeAg}$ positive and $52(42 \%)$ were anti-HBe-positive. The alanine aminotransferase levels in $\mathrm{HBeAg}$-positive patients were: mean $76 \mathrm{U} / \mathrm{l}$; range $40-210 \mathrm{U} / \mathrm{l}$. The corresponding values in the anti-HBe-positive group were: mean $84 \mathrm{U} / \mathrm{l}$; range $35-84 \mathrm{U} / 1$.

Group II (control group) included 30 patients with chronic hepatitis, 28 with antibodies to hepatitis $C$ virus (alanine aminotransferase range $60-248 \mathrm{U} / \mathrm{l}$, mean $153 \mathrm{U} / \mathrm{l}$ ) and 20 clinically healthy blood donors (alanine aminotransferase levels within the normal range). None of the 50 control subjects had serological markers of $\mathrm{HBV}$ infection.

\section{Hepatitis $B$ virus markers}

The hepatitis B surface antigen (HBsAg), the hepatitis B " $e$ " antigen ( $\mathrm{HBeAg})$, the antibody to hepatitis B "core" antigen (anti-HBc) and the antibody to hepatitis B " $\mathrm{e}$ " antigen (anti$\mathrm{HBe}$ ) were determined using commercial radioimmunoassays (Abbott Laboratories, North Chicago, ILL).

\section{Labelling of DNA probes}

Plasmid pcF80, containing four copies of cloned HBV-DNA, was kindly provided by Dr. Brechot (Institut Pasteur, Paris, France) (13). The plasmid DNA was digested with Eco RI and subjected to agarose electrophoresis. The HBV-DNA was retained in DEAE-cellulose and eluted by incubation in a buffer containing $1.5 \mathrm{~mol} / \mathrm{l} \mathrm{NaCl}$ buffer $10 \mathrm{mmol} / 1$ Tris $\cdot \mathrm{HCl}(\mathrm{pH}$ 7.5), $1 \mathrm{mmol} / 1 \mathrm{EDTA}$ at $37^{\circ} \mathrm{C}$.

Labelling of DNA probes was carried out as previously described $(14,15)$. Briefly:

a) Radioactive $\left({ }^{32} \mathrm{P}\right)$ probe: For the isotopic labelling, ${ }^{32} \mathrm{P}$-dATP (Amersham Corporation, Illinois, U.S.A.) was incorporated into HBV-DNA $(0.1 \mu \mathrm{g})$ by nick-translation, as recommended by the manufacturer of the kit (Nick Translation Reagent Kit, $\mathrm{BRL})$. The specific activity obtained was $4 \times 10^{8}$ counts $/ \mathrm{min}$ per $\mathbf{g}$.

b) Biotin-labelled probe: For the non-isotopic labelling, biotin11 dUTP (BRL) was incorporated into the HBV-DNA $(0.3 \mu \mathrm{g})$ by nick-translation according to the manufacturer's recommendations (BRL). The biotin-labelled probes were stored at $-20^{\circ} \mathrm{C}$. Their stability was tested in repeated assays for several months.

c) Digoxygenin-labelled probes: The HBV-DNA $(0.3 \mu \mathrm{g})$ was labelled by "random primed" incorporation of digoxygenindUTP following the instructions of the supplier (Boehringer Mannheim, SA).

\section{Preparation of serum samples}

Sera were prepared according to Scotto et al. (3), with some modifications. Briefly, $7 \mu \mathrm{l}$ of serum were directly denatured in $0.5 \mathrm{~mol} / 1 \mathrm{NaOH}, 1.5 \mathrm{~mol} / 1 \mathrm{NaCl}$ (final volume of $200 \mu \mathrm{l}$ ) for $10 \mathrm{~min}$, filtered on a nitrocellulose membrane (Schleicher \& Schuell, BA 85) and neutralized by immersion in $0.5 \mathrm{~mol} / \mathrm{l}$ Tris $\cdot \mathrm{HCl}(\mathrm{pH} 7.5), 1.5 \mathrm{~mol} / \mathrm{l} \mathrm{NaCl}$ for $10 \mathrm{~min}$. Filters were baked at $80{ }^{\circ} \mathrm{C}$ for $2 \mathrm{~h}$.

\section{Nucleic acid hybridization}

The nitrocellulose filters were always prehybridized for at least $2 \mathrm{~h}$ in a solution containing $12.5 \mathrm{~mol} / 1$ formamide, $0.75 \mathrm{~mol} / \mathrm{l}$ $\mathrm{NaCl}, 0.075 \mathrm{~mol} / \mathrm{l}$ sodium citrate, $0.02 \mathrm{~mol} / 1 \mathrm{Na}$ phosphate $(\mathrm{pH}$ 6.5), $5 \times$ Denhart's and $100 \mathrm{mg} / \mathrm{l}$ salmon sperm DNA at $42^{\circ} \mathrm{C}$. Hybridization was carried out in the same solution with either $100 \mu \mathrm{g} / \mathrm{l}$ of non-radioactive probe or $10 \mu \mathrm{g} / \mathrm{l}$ of radioactive probe. The filters were washed in a solution containing 0.015 mol $/ 1$ Neck, 0.0015 sodium citrate,, $0.0034 \mathrm{~mol} / 1$ SDS and then air dried.

\section{Detection of bound labelled DNA probes}

The filters hybridized with the radioactive DNA probe were autoradiographed at $-70^{\circ} \mathrm{C}$ with Kodak XAR-S film and Micron $\mathrm{R}$ intensifying screen.

Positive hybridization with biotin-labelled probes was visualized by incubation with streptavidin/alkaline phosphatase conjugate followed by coloured enzymatic reaction (5-bromo-4 chloro-3-indolyl phosphate and nitroblue tetrazolium salt) (BRL).

The detection of digoxygenin-labelled DNA was carried out by enzym-linked immunoassay using an antibody-conjugate (antidigoxygenin alkaline phosphatase conjugate) and the above described colorimetric reaction (Boehringer Mannheim, SA).

\section{Determination of sensitivity and specificity}

The sensitivity of each technique was determined by testing in duplicate decreasing dilutions (200 to $0.1 \mathrm{pg}$ ) of plasmid DNA pcF 80 in negative control serum samples. As a negative control plasmid pBR 322 at a concentration of 200 pg was used.

To verify the specificity of the assay, fractions of the serum samples that had given a positive test result for HBV-DNA were deproteinized by digestion with proteinase $\mathrm{K}(40 \mathrm{mg} / \mathrm{l})$ for $60 \mathrm{~min}$ at $37^{\circ} \mathrm{C}$, extracted with phenol/chloroform, and precipitated with ethanol. The resulting purified DNA was dissolved in water, denatured and applied to nitrocellulose filters. It was then tested in the same way as the serum samples.

\section{Results}

\section{Sensitivity and time required for testing}

The ${ }^{32} \mathrm{P}$-labelled probe and digoxygenin-labelled probe were able to detect as little as $1 \mathrm{pg}$ of cloned HBV-DNA in the spot hybridization test, while the biotin-labelled probe was able to detect $5 \mathrm{pg}$.

The time required for detection of serum HBV-DNA was $2-3$ hours for the non-radioactive probes and 16 hours for the isotopic probe (autoradiography).

\section{Comparison of hybridization results with im- munological markers}

HBV-DNA was detected in $60(49 \%)$ of $122 \mathrm{HBsAg}-$ positive serum samples with the ${ }^{32} \mathrm{P}$ and digoxygeninlabelled probes, and in $79(64 \%)$ sera with the biotin- 
Tab. 1. Comparison of results obtained with biotin, digoxygenin and ${ }^{32}$ P-labelled probes. The detection of HBV-DNA in serum is related to serological status on 88 serum samples.

\begin{tabular}{|c|c|c|c|c|}
\hline \multirow[t]{2}{*}{$\mathrm{N}$} & \multirow[t]{2}{*}{ Immunological markers } & \multicolumn{3}{|c|}{ HBV-DNA detection } \\
\hline & & Biotin & Digoxygenin & ${ }^{32} \mathrm{P}$ \\
\hline $\begin{array}{l}70 \\
52 \\
30 \\
20\end{array}$ & $\begin{array}{l}\mathrm{HBsAg}+/ \mathrm{HBeAg}+ \\
\mathrm{HBsAg}+/ \text { anti-HBe } \\
\text { HBsAg - /anti-HBc - } \\
\text { Blood-donors }\end{array}$ & $\begin{array}{c}* 74(91 \%) \\
* * 15(29 \%) \\
0 \\
0\end{array}$ & $\begin{array}{l}56(80 \%) \\
4 \\
0 \\
0\end{array}$ & $\begin{array}{rr}56 & (80 \%) \\
4 & (8 \%) \\
0 & \\
0 & \end{array}$ \\
\hline
\end{tabular}

* 8 of these were found be negative after deproteinization.

** 11 of these were found to be negative after deproteinization.

labelled probe. Fifty six ( $80 \%)$ serum samples from $70 \mathrm{HBeAg}$-positive chronic hepatitis patients were found to be positive for HBV-DNA by the three methods and $8(11 \%)$ more by the biotin-labelled probe, exclusively. In 52 anti-HBe-positive patients, HBV-DNA was found to be positive in $4(8 \%)$ serum samples by the three methods and $11(21 \%)$ more only by the biotin-labelled probe (tab. 1). Figure 1 demonstrates the results of sera HBV-DNA detection by the three hybridization methods.

After deproteinization, 19 serum samples, 8 from the $\mathrm{HBeAg}$-positive and 11 from the anti-HBe-positive group, which had previously given a positive test result by the biotin-labelled method, were found to be negative; these cases were considered to be falsepositive (tab. 1). There were no false positive results with the ${ }^{32} \mathrm{P}$ or digoxygenin-labelled methods.

None of the three techniques indicated the presence of HBV-DNA in the 30 samples from patients with chronic hepatitis without HBV markers, or in the 20 healthy subjects.

\section{Discussion}

Our results demonstrate that the non-radioactive techniques for detecting HBV-DNA in serum are a suitable alternative to the ${ }^{32} \mathrm{P}$-labelled probe because they are sensitive, rapid and reproducible. Of the nonradioactive probes, the best results were obtained with the digoxygenin-labelled probe, which permitted detection of as little as $1 \mathrm{pg}$ of HBV-DNA. This reached the sensitivity level of the ${ }^{32} \mathrm{P}$-labelled probe without the inconvenience of exposure to radiation. An additional advantage is the comparatively rapid detection for these methods ( $2-3$ hours). The biotin-labelled probe give a quick result, but the absolute sensitivity of the assay was about 5 times lower than that of the ${ }^{32} \mathrm{P}$ - or digoxygenin-labelled probes. Regarding specificity, the biotin-labelled probe produced $16 \%$ false positive results, while the ${ }^{32} \mathrm{P}$ - and digoxygenin-labelled probes produced no false positives. The deproteinization step improved the specificity of the biotin-labelled technique, but represented on increase in both cost and time. Our results for specificity and sensitivity with the digoxygenin-labelled assay are in
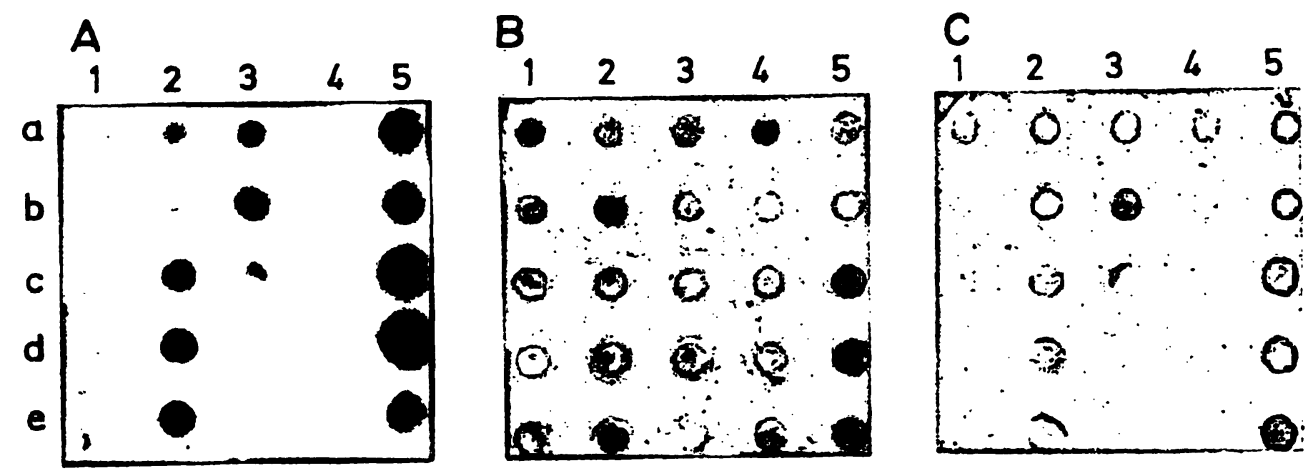

Fig. 1. Comparison of the detection methods. Serum samples from 25 patients were spotted on each of the three hybridization filters. Filter A was hybridized with a ${ }^{32}$ P-labelled probe. Filter B was hybridized with a biotin-labelled probe and filter $C$ was hybridized with a digoxygenin-labelled probe. The $(a-e)$ and $(1-5)$ series indicate the positions of the serum samples in the dot-blot apparatus. 
agreement with several studies of hybridization "in situ", and hybridization of DNA sequences amplified by polymerase chain reaction (PCR) $(16-18)$.

Another advantage of the non-radioactive techniques is that the hybridization conditions may be standardized; biotin and digoxygenin have relatively longer half-lives, while ${ }^{32} \mathrm{P}$ has a half-life of about two weeks. Thus, detection of HBV-DNA is easier, requires less time and money, and can be used in laboratories without special facilities. We found the colorimetric revelation of both digoxygenin and biotin to be of high quality and comparable to autoradiography; this agrees with results published by Leary et al. using other non-radioactive probes (19).

In earlier studies, serum $\mathrm{HBeAg}$ detection has been associated with $\mathrm{HBV}$ multiplication, hepatic damage and serum infectivity. However, the detection of sera $\mathrm{HBeAg}$ does not always indicate viral replication (3, 20). Indeed, serum HBV-DNA negativity may precede seroconversion from $\mathrm{HBeAg}$ to antiHBe; conversely, HBV-DNA positivity in anti-HBe-positive subjects

\section{References}

1. Brechot, C., Hadchoel, M., Scotto, J., Degos, F., Charnay, P., Trepo, C. \& Tiollais, P. (1981) Detection of hepatitis B virus DNA in liver and serum: a direct appraisal of the chronic carrier state. Lancet 2, 765-767.

2. Bonino, F., Hoyer, B., Nelson, J., Engle, R., Verme, G. \& Gerin, J. (1981) Hepatitis B virus DNA in the sera of HBsAg carriers: a marker of active hepatitis B virus replication in the liver. Hepatology 1, 386-391.

3. Scotto, J., Hadchouel, M., Hery, C., Yvart, J., Tiollais, P. \& Brecht, C. (1983) Detection of hepatitis B virus DNA in serum by a simple spot hybridization technique: Comparison with results for other viral markers. Hepatology 3 , 279-284.

4. Lieberman, H. M., Labrecque, D. R., Kew, M. C., Hadzyiannis, S. J. \& Shafritz, D. A. (1983) Detection of hepatitis $B$ virus DNA directly in human serum by a simplified molecular hybridization test: Comparison to $\mathrm{HBeAg} /$ antiHBe status in $\mathrm{HBsAg}$ carriers. Hepatology 3, 285291.

5. Tchen, P., Fuchs, R. P., Sage, E. \& Leng, M. (1984) Chemically modified nucleic acids as immunodetectable probes in hybridization experiments. Proc. Natl. Acad. Sci. USA $81,3466-3470$.

6. Agrowal, S., Cristodoulou, C. \& Gait, M. (1984) Efficient method for DNA hybridization. Nucleic Acid Res. 12, 3435-3444.

7. Foster, A. C., Mclnnes, J. L., Skingle, O. C. \& Symons, R. $H$. (1985) Non-radioactive hybridization probes prepared by the chemical labelling of DNA or RNA with a novel reagent photobiotin. Nucleic Acid Res. 13, 745-761.

8. Viscidi, R. P., Connelly, C. J. \& Yolken, R. H. (1986) Novel chemical method for the preparation of nucleic acid for non-isotopic hybridization. J. Clin. Microbiol. 23, 311317. with chronic hepatitis, may indicate persistent HBV replication (18). These possibilities have been confirmed using our non-radioactive spot test: $80 \%$ of the $70 \mathrm{HBeAg}$ carriers were positive for HBV-DNA and $8 \%$ of the 52 anti-HBe-positive carriers were positive for HBV-DNA.

In conclusion, the most efficient non-radioactive method in our hands was the immunological detection of digoxygenin-labelled DNA, which demonstrated a sensitivity comparable to the isotopic technique, and better specificity than biotin-labelled DNA, suggesting that this method could be a useful tool for clinical diagnosis and monitoring of viral replication in chronic type $B$ hepatitis.

\section{Acknowledgement}

This work was supported in part by a grant from FISS 90-0938.

The authors wish to thank Montserrat Gimferrer and Carmen Molinos for their nursing assistance.
9. Dooley, S., Radtke, J., Blin, N. \& Unteregger, G. (1988) Rapid detection of DNA-binding factors using proteinblotting and digoxygenin-UTP marked probes. Nucleic Acids Res. 16, 11829.

10. Holtke, H. J., Seibl, R., Burg, J., Muhlegger, K. \& Kesșler, C. (1990) Non-radioactive labeling and detection of nucleic acids: II optimization of the digoxygenin system. Biol. Chem. Hoppe-Seyler 371, 929-938.

11. Larzul, D., Thiers, V., Courouce, A. M., Brechot, C. \& Guesdon, J. L. (1987) Non-radioactive hepatitis B virus DNA probes for detection of HBV-DNA in serum. J. Hepatol. 57, 199-204.

12. Quibriac, M., Petitjean, J., Novel, M. \& Freymuth, F. (1987) Non radioactive spot hybridization test for detection of hepatitis B virus DNA in serum. Ann. Inst. Pasteur 138, $377-384$.

13. Charnay, P., Pourcel, C. \& Fritsch, A. (1980) Cloning in E. coli and physical structure of hepatitis B virus DN.A. Proc. Natl. Acad. Sci. USA 76, 2222-2226.

14. Cásacuberta, J. M., Jardi, R., Buti, M., Puigdomenech, P. \& Sansegundo, B. (1988) Comparison of different nonisotopic methods for hepatitis B virus detection in human serum. Nucleic Acids Res. 16, 11834.

15. Genesca, J., Jardi, R., Buti, M., Vives, L., Prat; S., Esteb̉an, J. I., Esteban, R. \& Guardia, J. (1987) Hepatitis B virus replication in acute $B$, acute hepatitis $B$ virus-hèpatitis delta virus coinfection and acute hepatitis delta superinfection. Hepatology 7, $569-572$.

16. Leary, J., Brigati, D. J. \& Wards, D. C. (1983) Rapid and sensitive colorimetric method for visualizing biotin-labeled DNA probes hybridized to DNA or RNA immobilized on nitrocellulose: Bio-blots. Proc. Natl. Acad. Sci. USA 80, $4045-4049$ 
17. Heiles, H. B. J., Genersch, E., Kessler, C., Neumann, R. \& Eggers, H. J. (1988) In situ hybridization with digoxygeninlabeled DNA of human papillomaviruses in HeLa and $\mathrm{SiHa}$ cells. BioTechniques $6,978-981$.

18. Gentilomi, G., Musiani, M., Zerbini, M., Gallinella, G., Gibellini, B. \& La Placa, M. (1989) A hybrido-immunocytochemical assay for the in situ detection of cytomegalovirus DNA using digoxygenin-labelled probes. J. Immunol. Methods $125,177-183$.

19. Kion, T. \& Haas, O. A. (1990) Nonradioactive labeling of probe with digoxygenin by polymerase chain reaction. Anal. Biochem. 188, 335-337.
20. Hadzyyannis, S. J., Lieberman, H. M., Karvountzis, G. C. \& Shafritz, D. A. (1983) Analysis of liver disease, nuclear $\mathrm{HBcAg}$, viral replication, and hepatitis $B$ virus DNA in liver and serum of $\mathrm{HBeAg} / \mathrm{antiHBe}$ positive carriers of hepatitis B virus. Hepatology 3, 656-662.

21. Lok, A. S. F., Hadziyannis, S. J. \& Weller, I. V. D. (1984) Contribution of low level HBV replication to continuing inflammatory activity in patients with anti-HBe positive chronic hepatitis B virus infection. Gut 25, 1283-1287.

\author{
Maria Buti \\ Servicio de Hepatología \\ Hospital General Valle de Hebrón \\ Paseo Valle de Hebrón s/n \\ Barcelona 08035 \\ Spain
}


